\title{
Ship Collision Avoidance Decision Model and Simulation Based on Collision Circle
}

\author{
J. Zhang \& Q. Hu \\ Merchant Marine College, Shanghai Maritime University, Shanghai, China \\ B. Liao \\ COSCO Shipping Seafarer Manangement CO,LTD, Shanghai, China
}

\begin{abstract}
In order to give consideration to both comprehensive evaluation and efficient decision-making in collision avoidance decision-making process, a collision avoidance decision-making model based on collision circle is proposed by introducing the concept of collision circle. Firstly, the factors causing ship collision are analyzed. Secondly, the static and dynamic characteristics of collision circles are analyzed and summarized by using collision circle simulation cases. Thirdly, based on the static characteristics, a reasonably distributed collision avoidance decision model of (Possible Point of Collision,PPC) was established. Finally, the spatial data operations core algorithm (Java Topology Suite, JTS) is used for logical operation and visualization, so as to realize the ship collision avoidance evaluation and decision. The decision model was used to verify the accident scenario of "SANCHI", and the results showed that the obtained collision avoidance scheme was reasonable and in line with the "International Regulations for Preventing Collisions at Sea" and safety requirements, thus providing a reference for maritime operators to avoid collisions between ships.
\end{abstract}

\section{INTRODUCTION}

With the rapid development of the world economy, the rapid increase in the number of ships, the increasing traffic on the water, the frequent port access to ships and some human factors have caused the frequent occurrence of water traffic accidents, which has aroused widespread concern. In the investigation of the causes of collision accidents, more than $80 \%$ were caused by human factors that could not fully assess the collision risk of the ship and the implementation of efficient decision-making ${ }^{[1]}$.

At present, in order to solve the problem of ship navigation safety, domestic and foreign scholars have done a lot of research and made some progress in ship collision avoidance. Scholars use methods such as forecasting and identifying collision collision risk areas ${ }^{[2-3]}$, ship dynamic steering model method ${ }^{[4]}$, and ship automatic collision avoidance model method ${ }^{[5-7]}$ to achieve effective collision avoidance. In addition, Liao bingjun ${ }^{[8]}$ identified and controlled the risk of ship collision according to the law of situational awareness in practice, and proposed the related concepts and basic usage of safety situation chart. $\mathrm{Hu}$ Shenping ${ }^{[9]}$ based on the analysis of ship's encounter, put forward with the Distance to Closest Point of Approach (DCPA) and Time to Closest Point of Approach (TCPA) on the basis of ship maneuvering freedom of collision avoidance action stage, stage of risk of collision, qualitative and quantitative analysis of the urgent situation, for ship collision liability division and ship maneuvering action to provide the reference. Hu Qiaoer et al. [10], aimed at mutual benefit and overall optimization, proposed to solve the problem of ship collision avoidance from a more humanized and practical perspective based on the theory of negotiated ship collision avoidance, and 
verified and analyzed the feasibility of the theory through simulation data. Youngjun You et al. [11] proposed to take collision ratio as an indicator to determine the time to start collision avoidance maneuver, and to evaluate the effectiveness of inferred collision ratio according to the dynamic characteristics of the ship and collision prevention algorithm. With the maturity and perfection of artificial intelligent technology, through the people ${ }^{[12]}$ workers swarm algorithm, genetic algorithm [13], mimicry physics optimization algorithm ${ }^{[14]}$, simulated annealing algorithm ${ }^{[15]}$, the particle swarm algorithm ${ }^{[16]}$ based on depth competition $Q$ learning algorithm and $\mathrm{A}^{*}$ algorithm ${ }^{[17]}$ calculation of collision risk and loss of voyage, such as the objective function to achieve the optimal give way to the timing, safety, avoiding collision, and resume to resume time. At the same time, scholars also use the advantages of intelligent algorithms and models to combine the theory of ship collision avoidance field, ship dynamic boundary theory, ship motion mathematical model and domain model with various intelligent algorithms ${ }^{[18-22]}$ to establish the optimization model of ship automatic collision avoidance. In the above studies, although relevant intelligent algorithms are used to put forward collision avoidance schemes, the change rules of collision circles and possible collision points in collision avoidance process have not been fully clarified, and the guiding significance of collision avoidance has not been fully explained. The details are as follows: 1 . The changing rules of collision circle in various encounters of ships are not fully explained; 2 . Limited to the single-ship analysis, the PPC of the two ships was not comprehensively analyzed;3. The dynamic variation rules of PPC and Possible Circle of Collision (PCC) and the specific model used for Collision avoidance decision are not fully explained.

When a ship is sailing at sea, its speed and heading are greatly affected by external factors. Therefore, it is difficult to make a comprehensive evaluation and efficient decision for collision avoidance. The collision circle model is determined by the speed, course, position and other factors of the two ships, which is especially suitable for the situation of unstable speed and course changes. Fully sorting out the distribution rules of collision circle greatly improves the comprehensive evaluation and efficient decision-making of collision avoidance of ships. This paper analyzes the static distribution and dynamic distribution rules of PCC and PPC, summarizes the static distribution and dynamic change rules of PCC and PPC, establishes the collision avoidance decision-making model of ships based on collision circle, and applies the model to the accident scene of "SANCHI" to verify the reliability of the model with an example.

\section{COLLISION CIRCLE PRINCIPLE AND RELATED CONCEPTS}

\subsection{Definition of the Apollonius circle}

Apollonius circle theorem: the ratio of the distance between the moving point $\mathrm{P}$ and the two points $\mathrm{A}$ and $B$ is equal to the fixed value $k(k>1)$, then the trajectory of point $\mathrm{P}$ is $\mathrm{A}$ circle with the diameter of the line connecting the fixed value $\mathrm{k}$ to the inner point $\mathrm{C}$ and the outer point $\mathrm{D}$, as shown in figure 1 .

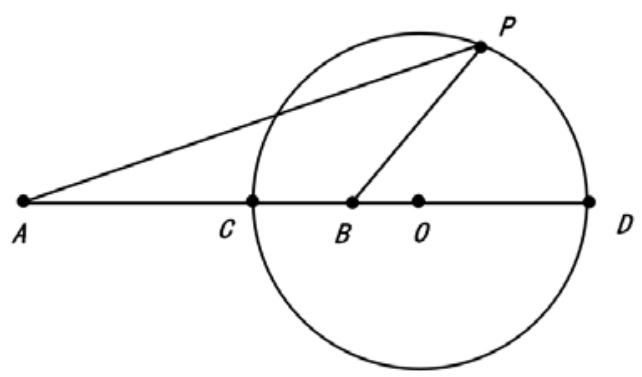

Figure 1 Model of an Apollonius circle

In FIG. 1, the distance ratio from point $\mathrm{P}$ to point $\mathrm{A}$ and point $\mathrm{B}$ is $\mathrm{A}$ fixed value $\mathrm{k}$. According to the theorem, all points satisfying this condition form $\mathrm{A}$ circle. Let $\mathrm{B}$ be the origin of the coordinate $(0,0), \mathrm{A}$ be the coordinate $(-a, 0)$, and the moving point $\mathrm{P}(\mathrm{x}, \mathrm{y})$.

Equation of a circle:

$\left(k^{2}-1\right)\left(x^{2}+y^{2}\right)+2 a x-a^{2}=0$

The radius $R$ is:

$$
R=\frac{a k}{k^{2}-1}
$$

The center coordinate $O$ is:

$$
\left(\frac{a k^{2}}{k^{2}-1}, 0\right)
$$

\subsection{Definition of collision circle}

The collision circle is the specific application of the Apollonis circle in collision avoidance. Let point A be the position where ship $A$ is located. The distance from point $A$ to point $P$ is S1. Point $B$ is the position where ship B is located. The distance from point B to point $P$ is S2. S1 is the distance that A ship sails within a certain time $t$, and $S 2$ is the distance that $B$ ship sails within the same time $t$, then the distance ratio problem is converted into a speed ratio problem.

In the collision circle: $k>1$, it means that the speed of the A ship is faster than that of the B ship; when $\mathrm{k}=1$, it means that the set of $\mathrm{P}$ is not the collision circle, and it is the vertical bisector of the connection between the A ship and the B ship; when $k<1$, the role of the A ship and the B ship are fast and slow, and the principle is the same. This paper only analyzes the case of $k>1$, which can explain the relevant change rules.

\subsection{Concepts and definitions related to PCC, PPC and $P A D$}

PCC refers to the possible collision circle. It refers to the collection of all positions at the same place that 
can be reached at the same time when the two ships have different speeds. When the two ships are at the same speed, it is the vertical bisector of the line connecting the two ships.

PPC is a possible collision point, which refers to the intersection of the two ship's heading lines with the PCC.

PAD is the predicted danger area. Since the ship needs to pass within a safe distance, it is assumed that the target ship maintains speed and direction, and the target ship PPC is calculated through a certain function to form an extended area, indicating the potential collision area when the target ship maintains speed and direction. If avoiding this area, the two ships can pass within a safe distance. However, the formation process of PAD involves complex function calculation, and the avoidance effect of different schemescannot be accurately evaluated, making it difficult to make decisions in complicated situations.

\subsection{Generation rule of collision center and radius}

According to the formula of the center and radius of the collision circle, the following rules are summarized:

1 The coordinates and radius of the center of the collision circle are related to the distance $\mathrm{D}$ and the speed ratio $\mathrm{k}$ between the two ships, and have nothing to do with the course.

2 The closer $\mathrm{k}$ is to 1 , the farther the center is and the larger the radius is, When the two ships change the speed, the speed ratio changes accordingly. If the speed ratio is increased, the center distance and radius decrease, the speed ratio decreases, and the center distance and radius increase. When $\mathrm{k}$ is in infinite state, the radius of the collision circle gradually shrinks to 0 , which is the B ship position; when $k=1$, the set of possible collision points is the vertical bisector of the $\mathrm{AB}$ connection; when $k<1$, the A ship and the B ship has a fast and slow ship transition, and the collision circle is located on the side of the A ship.

3 When the speed ratio $\mathrm{k}$ is constant, the center distance and radius are proportional to the distance between the two ships. The two ships will gradually approach the distance, and the distance and radius of the center of the collision circle will gradually become smaller.

4 The center of the collision circle is located on the side of the slow ship connecting the two ships. When the relative position of the fast ship changes, when one ship crosses the bow line of the other ship, the collision circle rotates accordingly and the arc of the collision circle cutting by the slow ship changes.

5 Ship A is fast ship, which is located outside PCC. There are 0 2 intersection points between ship A's heading line and PCC (represented by E and F), as shown in FIG. 2a, 2b and 2c. Ship B is a slow ship, which is located in PCC. There is only one intersection point between ship B's heading line and PCC (represented by $\mathrm{M}$ ), as shown in figure $2 \mathrm{~d}$.

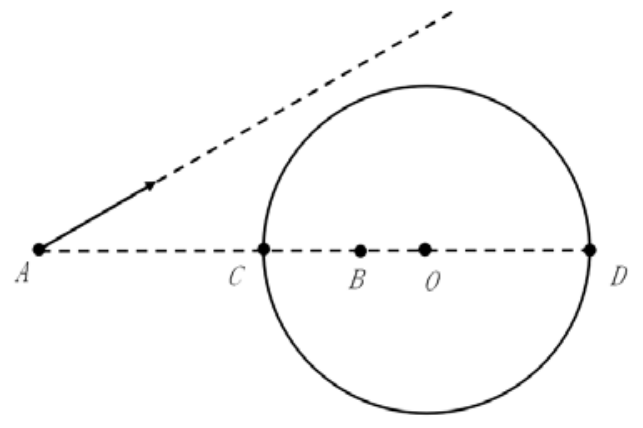

a) A ship produces 0 PPC

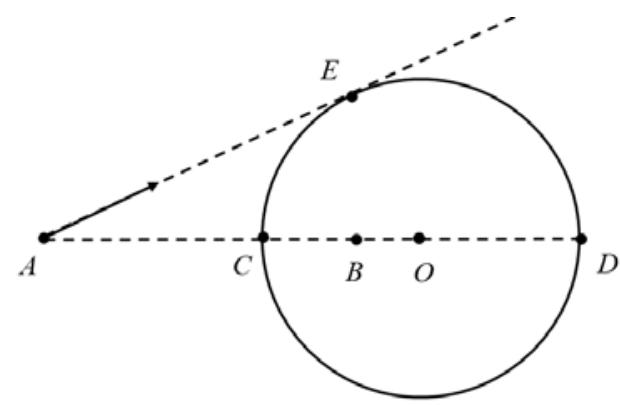

b) A ship produces 1 PPC

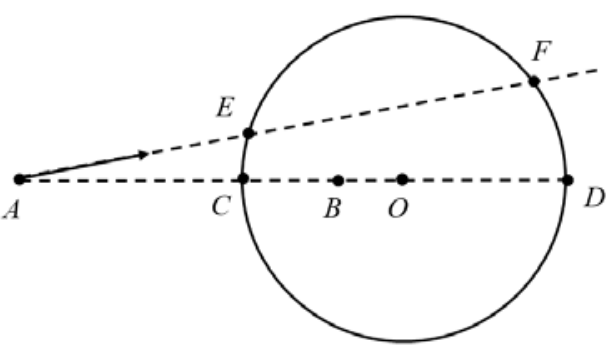

c) A ship produces $2 \mathrm{PP}$

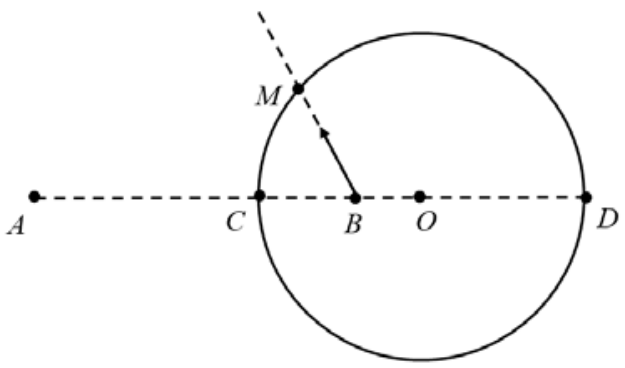

d) B ship produces 1 PPC

Figure 2. Distribution rule of PPC generated by two ships on the collision circle

\subsection{Establish collision circle collision avoidance model}

The collision circle is a collection of all possible collision points (the vertical bisector of the two ship lines at constant speed), which is characterized by the use of a simple formula to exhaust all possibilities.

According to the production rules of PCC and PPC, if the PPC of two ships overlaps, it means that the two ships will collide at the overlapping PPC point. If the PPC of two ships is very close, then there is a risk of collision between the two ships. Therefore, whether the PPC distribution is reasonable plays a crucial role in the collision between two ships. Based 
on this, the ship collision avoidance decision model is established to judge whether the PPC distribution is reasonable on the one hand and evaluate whether the decision plan is effective on the other hand.

The establishment process of collision avoidance model :(1) forming collision circle;(2) calculate the PPC of two ships;(3) take all PPC as the center of the circle and set the distance parameter as the radius as the circle to form the circle "Distribution diagram of PPC". (4) keep the course lines of both sides away from each other's "PPC distribution model".

\section{STATIC DISTRIBUTION LAW AND DYNAMIC DEVELOPMENT LAW OF PCC AND PPC IN TWO SHIPS}

\subsection{Static distribution law of PPC of the two ships}

By analyzing the PPC generated by the two ships at the same time, the current situation of the two ships and the collision avoidance effect corresponding to each course can be evaluated more comprehensively, and the collision avoidance problem can be converted into the PPC distribution problem of the two ships.

When evaluating the situation with the distribution problem of two ships' PPC, the following situations will be distinguished, as shown in figure 3:

1 When the PPC of the two ships overlaps ( $N$ denotes the overlap), it means that the two ships will collide at the overlapping point $\mathrm{N}$, as shown in FIG. 3a;

2 Close PPC distance between the two ships indicates the existence of collision risk, as shown in FIG. 3b;

3 The distance between the two ships' PPC is long, radian and far away from each other's course line, indicating that there is no risk of collision, as shown in FIG. 3c;

4 The PPC of the two ships is located on both sides of the connecting line of the two ships, indicating the obvious trend, as shown in FIG. 3d;

5 When ship A (clipper) has no intersection point with the collision circle, it means that ship B has no ability to catch up with ship A and there will be no collision, as shown in FIG. 3e.

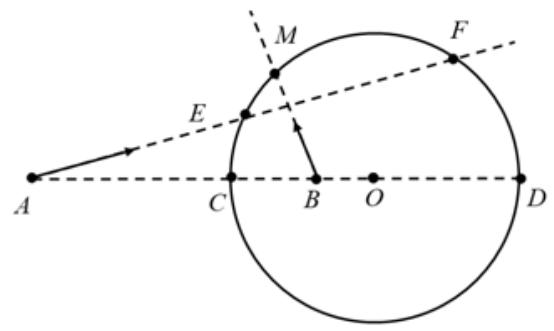

a) Collision

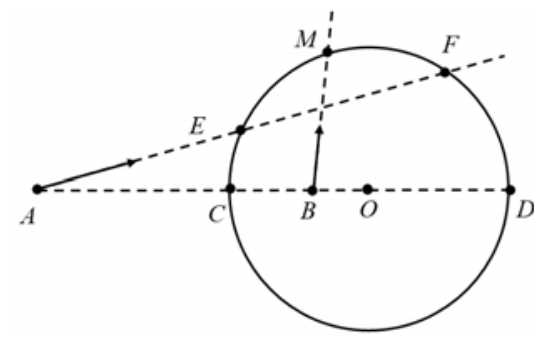

b) Risk of collision

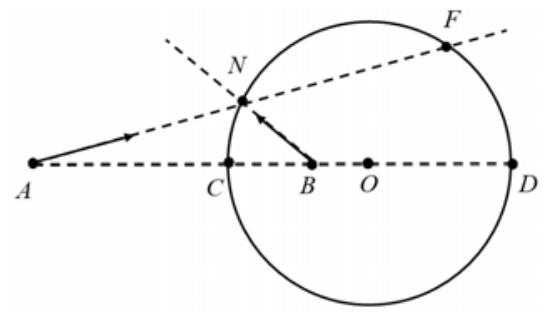

c) No collision risk

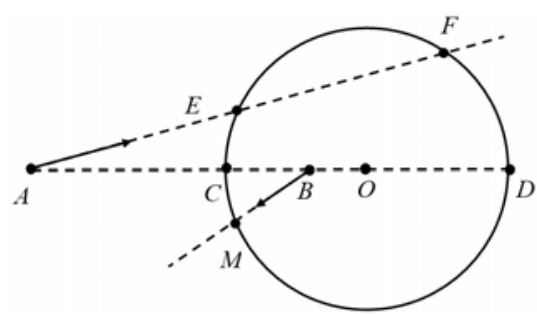

d) Obvious security situation

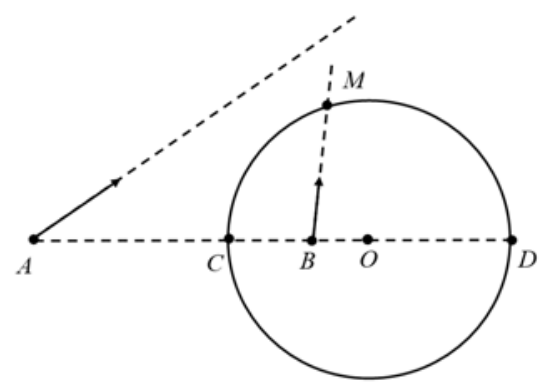

e) Clipper has no intersection with collision circle Figure 3 Influence of PPC distribution on the collision circle of two ships on the situation

\subsection{Dynamic development rules of PPC and PCC of the two ships}

\subsubsection{Simulation of dynamic development rule when PPC overlaps}

The ship collision avoidance simulation platform is built by JAVA language, $X$ represents the longitude of the coordinate axis, $Y$ represents the coordinate axis representing the latitude, and the scale unit is nautical mile (n mile). In order to clearly observe the change law, the A ship, the heading line and the distribution circle are marked in red color; the B ship, the heading line and the distribution circle are marked in blue color; the collision circle is marked in black color. Through the simulation platform test, the two ships collided and observe the dynamic development of PCC and PPC.

Simulation scenarios are shown in table 1. 
Table 1. Collision scenarios

\begin{tabular}{llllll}
\hline time & ships name & ships position & speed $/ \mathrm{kn}$ & course $/\left(^{\circ}\right)$ & PPC position \\
\hline $00: 00: 00$ & A ship & $\left(32^{\circ} 0.0000^{\prime} \mathrm{N}, 123^{\circ} 0.0000^{\prime} \mathrm{E}\right)$ & 20 & 000 & $\left(32^{\circ} 3.3333^{\prime} \mathrm{N}, 123^{\circ} 0.0000^{\prime} \mathrm{E}\right)$ \\
& $B$ ship & $\left(32^{\circ} 4.5000^{\prime} \mathrm{N}, 123^{\circ} 0.0000^{\prime} \mathrm{E}\right)$ & 10 & 180 & $\left(32^{\circ} 3.3333^{\prime} \mathrm{N}, 123^{\circ} 0.0000^{\prime} \mathrm{E}\right)$ \\
$00: 06: 00$ & A ship & $\left(32^{\circ} 2.0000^{\prime} \mathrm{N}, 123^{\circ} 0.0000^{\prime} \mathrm{E}\right)$ & 20 & 000 & $\left(32^{\circ} 3.3333^{\prime} \mathrm{N}, 123^{\circ} 0.0000^{\prime} \mathrm{E}\right)$ \\
& $B$ ship & $\left(32^{\circ} 4.0000^{\prime} \mathrm{N}, 123^{\circ} 0.0000^{\prime} \mathrm{E}\right)$ & 10 & 180 & $\left(32^{\circ} 3.3333^{\prime} \mathrm{N}, 123^{\circ} 0.0000^{\prime} \mathrm{E}\right)$ \\
$00: 09: 00$ & A ship & $\left(32^{\circ} 3.0000^{\prime} \mathrm{N}, 123^{\circ} 0.0000^{\prime} \mathrm{E}\right)$ & 20 & 000 & $\left(32^{\circ} 3.333^{\prime} \mathrm{N}, 123^{\circ} 0.0000^{\prime} \mathrm{E}\right)$ \\
& $B$ ship & $\left(32^{\circ} 3.5000^{\prime} \mathrm{N}, 123^{\circ} 0.0000^{\prime} \mathrm{E}\right)$ & 10 & 180 & $\left(32^{\circ} 3.3333^{\prime} \mathrm{N}, 123^{\circ} 0.0000^{\prime} \mathrm{E}\right)$ \\
$00: 09: 36$ & A ship & $\left(32^{\circ} 3.2000^{\prime} \mathrm{N}, 123^{\circ} 0.0000^{\prime} \mathrm{E}\right)$ & 20 & 000 & $\left(32^{\circ} 3.3333^{\prime} \mathrm{N}, 123^{\circ} 0.0000^{\prime} \mathrm{E}\right)$ \\
& $B$ ship & $\left(32^{\circ} 3.4000^{\prime} \mathrm{N}, 123^{\circ} 0.0000^{\prime} \mathrm{E}\right)$ & 10 & 180 & $\left(32^{\circ} 3.3333^{\prime} \mathrm{N}, 123^{\circ} 0.0000^{\prime} \mathrm{E}\right)$ \\
\hline
\end{tabular}

The simulation test is shown in figure 4 .

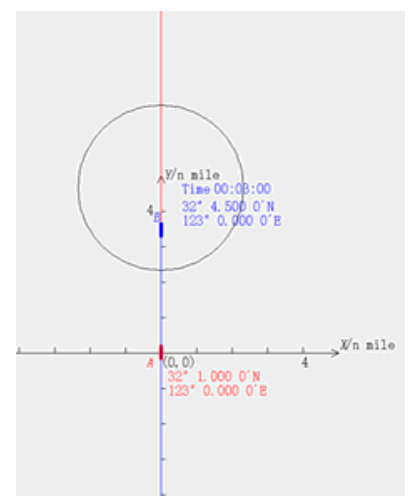

a) 10 min before collision

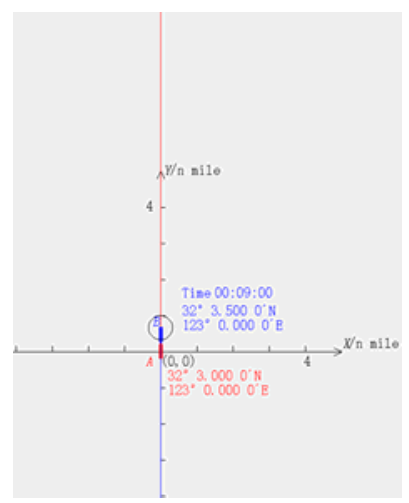

c) 1 min before collision Figure 4 . Simulation of dynamic development rule of
collision

According to the simulation test, when the PPC of two ships overlaps, the collision circle shrinks to the PPC point until the radius is 0 with the gradual approach of the two ships;The position of the common PPC point remains unchanged, and the two ships move towards the common PPC point and eventually collide at the PPC point. The course lines of the two ships will divide the collision circle in the same radian ratio.

The whole process of change is presented as a whole in one figure, and different collision situations can also be described in the same way, as shown in figure 5 .

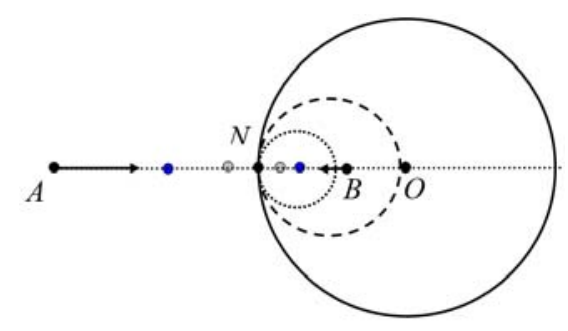

a) Collision situation

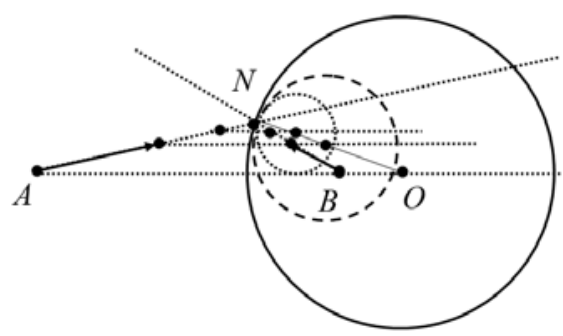

b) Cross collision situation

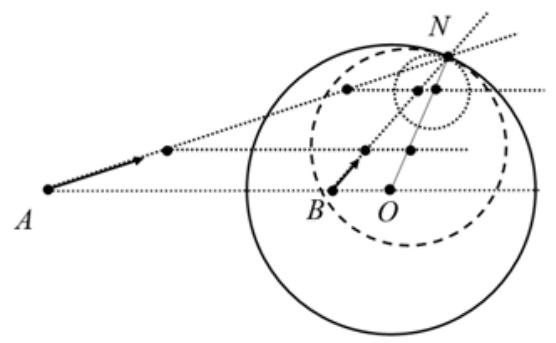

c) Overtaking collision situation

Figure 5. Dynamic development rules of collision circles when collision occurs in different situations

\subsubsection{Through the simulation of the accident case of "SANCHI", the dynamic development law of PPC in the near distance was analyzed}

Jan 6, 2018 at about 19:50 PM, Panamanian oil tanker "SANCHI" collided with Hong Kong bulk carrier "CF CRYSTAL" about 160 nautical miles east of the Yangtze river estuary, resulting in the whole ship of "SANCHI" caught fire and sank on January 14,2018 . The accident caused a large number of casualties, property losses and serious environmental pollution. By collecting relevant information of "SANCHI" accident, the simulation system was input to observe the dynamic development rules of PCC and PPC when the collision point was very close. The simulation scenes are shown in table 2 . 
Table 2. Simulation scenarios of "SANCHI" accident

\begin{tabular}{|c|c|c|c|c|c|c|}
\hline time & ships name & ships position & speed/kn & course $/\left(^{\circ}\right)$ & A ship PPC position & B ship PPC position \\
\hline \multirow[t]{2}{*}{ 19:40:08 } & $A$ ship & $\begin{array}{l}\left(30^{\circ} 49.3150^{\prime} \mathrm{N},\right. \\
\left.124^{\circ} 57.6740^{\prime} \mathrm{E}\right)\end{array}$ & 10.4 & 358 & $\begin{array}{l}\left(30^{\circ} 51.2275^{\prime} \mathrm{N},\right. \\
\left.124^{\circ} 57.6072^{\prime} \mathrm{E}\right)\end{array}$ & \\
\hline & $B$ ship & $\begin{array}{l}\left(30^{\circ} 52.8032^{\prime} \mathrm{N}^{\prime}\right. \\
\left.124^{\circ} 59.5038^{\prime} \mathrm{E}\right)\end{array}$ & 13.2 & 226 & & $\begin{array}{l}\left(30^{\circ} 51.1663^{\prime} \mathrm{N},\right. \\
\left.124^{\circ} 57.8088^{\prime} \mathrm{E}\right)\end{array}$ \\
\hline \multirow[t]{2}{*}{ 19:43:08 } & $A$ ship & $\begin{array}{l}\left(30^{\circ} 49.8370^{\prime} \mathrm{N}\right. \\
\left.124^{\circ} 57.6500^{\prime} \mathrm{E}\right)\end{array}$ & 10.4 & 358 & $\begin{array}{l}\left(30^{\circ} 51.2161^{\prime} \mathrm{N},\right. \\
\left.124^{\circ} 57.6018^{\prime} \mathrm{E}\right)\end{array}$ & \\
\hline & $B$ ship & $\begin{array}{l}\left(30^{\circ} 52.3096^{\prime} \mathrm{N},\right. \\
\left.124^{\circ} 58.9917^{\prime} \mathrm{E}\right)\end{array}$ & 13.2 & 226 & & $\begin{array}{l}\left(30^{\circ} 51.1407^{\prime} \mathrm{N},\right. \\
\left.124^{\circ} 57.7812^{\prime} \mathrm{E}\right)\end{array}$ \\
\hline \multirow[t]{2}{*}{ 19:47:09 } & $A$ ship & $\begin{array}{l}\left(30^{\circ} 50.5380^{\prime} \mathrm{N},\right. \\
\left.124^{\circ} 57.6150^{\prime} \mathrm{E}\right)\end{array}$ & 10.4 & 358 & $\begin{array}{l}\left(30^{\circ} 51.1865^{\prime} \mathrm{N},\right. \\
\left.124^{\circ} 57.5923^{\prime} \mathrm{E}\right)\end{array}$ & \\
\hline & $B$ ship & $\begin{array}{l}\left(30^{\circ} 51.6706^{\prime} \mathrm{N}^{\prime}\right. \\
\left.124^{\circ} 58.2596^{\prime} \mathrm{E}\right)\end{array}$ & 13.2 & 226 & & $\begin{array}{l}\left(30^{\circ} 51.1299^{\prime} \mathrm{N},\right. \\
\left.124^{\circ} 57.6997^{\prime} \mathrm{E}\right)\end{array}$ \\
\hline \multirow[t]{2}{*}{ 19:50:09 } & $A$ ship & $\begin{array}{l}\left(30^{\circ} 51.0580^{\prime} \mathrm{N},\right. \\
\left.124^{\circ} 57.5830^{\prime} \mathrm{E}\right)\end{array}$ & 10.4 & 358 & $\begin{array}{l}\left(30^{\circ} 51.1515^{\prime} \mathrm{N},\right. \\
\left.124^{\circ} 57.5797^{\prime} \mathrm{E}\right)\end{array}$ & \\
\hline & $B$ ship & $\begin{array}{l}\left(30^{\circ} 51.1873^{\prime} \mathrm{N},\right. \\
\left.124^{\circ} 57.6956^{\prime} \mathrm{E}\right)\end{array}$ & 13.2 & 226 & & $\begin{array}{l}\left(30^{\circ} 51.1191^{\prime} \mathrm{N},\right. \\
\left.124^{\circ} 57.6250^{\prime} \mathrm{E}\right)\end{array}$ \\
\hline
\end{tabular}

Table 3 Scenario of safe passage of the bow line

\begin{tabular}{llllll}
\hline time & ships name & ships position & speed $/ \mathrm{kn}$ & course $/\left({ }^{\circ}\right)$ & PPC position \\
\hline $00: 00: 36$ & A ship & $\left(32^{\circ} 0.2000^{\prime} \mathrm{N}, 123^{\circ} 0.0000^{\prime} \mathrm{E}\right)$ & 20 & 000 & $\left(32^{\circ} 3.5645^{\prime} \mathrm{N}, 123^{\circ} 0.0000^{\prime} \mathrm{E}\right)$ \\
& $B$ ship & $\left(32^{\circ} 4.9000^{\prime} \mathrm{N}, 123^{\circ} 1.0000^{\prime} \mathrm{E}\right)$ & 10 & 180 & $\left(32^{\circ} 3.2960^{\prime} \mathrm{N}, 123^{\circ} 1.0000^{\prime} \mathrm{E}\right)$ \\
00:03:00 & A ship & $\left(32^{\circ} 1.0000^{\prime} \mathrm{N}, 123^{\circ} 0.0000^{\prime} \mathrm{E}\right)$ & 20 & 000 & $\left(32^{\circ} 3.6410^{\prime} \mathrm{N}, 123^{\circ} 0.0000^{\prime} \mathrm{E}\right)$ \\
& $B$ ship & $\left(32^{\circ} 4.5000^{\prime} \mathrm{N}, 123^{\circ} 1.0000^{\prime} \mathrm{E}\right)$ & 10 & 180 & $\left(32^{\circ} 3.2728^{\prime} \mathrm{N}, 123^{\circ} 1.0000^{\prime} \mathrm{E}\right)$ \\
$00: 06: 36$ & $A$ ship & $\left(32^{\circ} 2.2000^{\prime} \mathrm{N}, 123^{\circ} 0.0000^{\prime} \mathrm{E}\right)$ & 20 & 000 & \\
& $B$ ship & $\left(32^{\circ} 3.9000^{\prime} \mathrm{N}, 123^{\circ} 1.0000^{\prime} \mathrm{E}\right)$ & 10 & 180 & $\left(32^{\circ} 3.2004^{\prime} \mathrm{N}, 123^{\circ} 1.0000^{\prime} \mathrm{E}\right)$ \\
$00: 10: 00$ & $A$ ship & $\left(32^{\circ} 3.3333^{\prime} \mathrm{N}, 123^{\circ} 0.0000^{\prime} \mathrm{E}\right)$ & 20 & 000 & \\
& $B$ ship & $\left(32^{\circ} 3.3333^{\prime} \mathrm{N}, 123^{\circ} 1.0000^{\prime} \mathrm{E}\right)$ & 10 & 180 & $\left(32^{\circ} 2.7592^{\prime} \mathrm{N}, 123^{\circ} 1.0000^{\prime} \mathrm{E}\right)$ \\
\hline
\end{tabular}

Simulation of "SANCHI" accident, see figure 6.
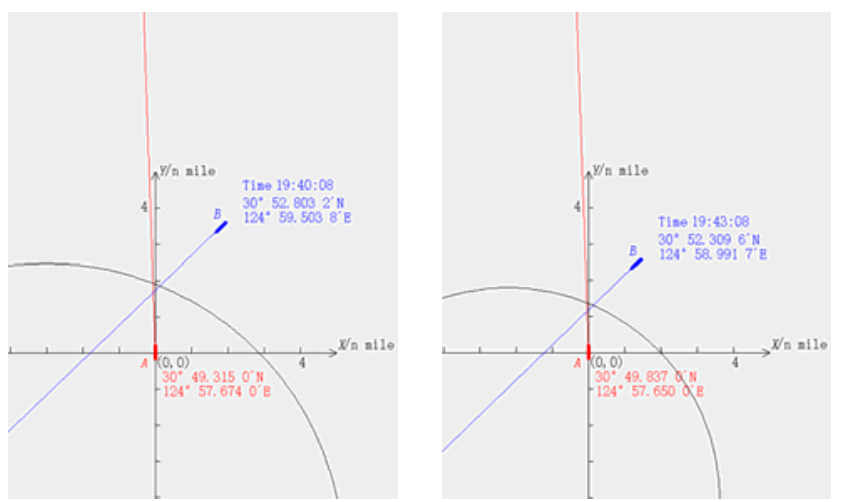

a) 10 min before collision

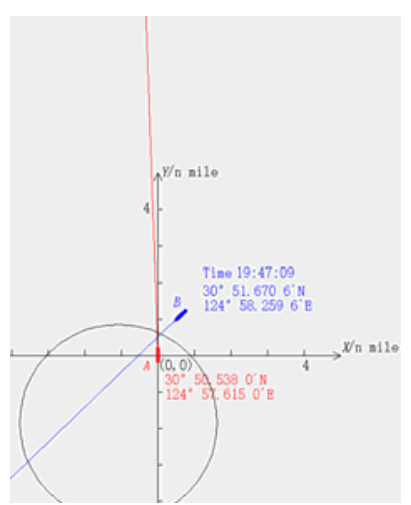

c) 3 min before collision

Figure 6. Accident simulation of "SANCHI"
According to the simulation test, when the PPC of two ships is very close, the collision circle shrinks towards the PPC point until the two ships are closest as the two ships approach gradually. The change range of PPC position generated by each ship is related to the change range of relative azimuth of the two ships. In this case, the change range is very small. The change of the proportion of the collision circle divided by the course lines of the two ships is very small. When the PPC generated by the two ships is relatively close, there is a risk of collision. When the size of the two ships is large, the ship cannot be regarded as a particle, because collision may still occur. b) 7 min before collision

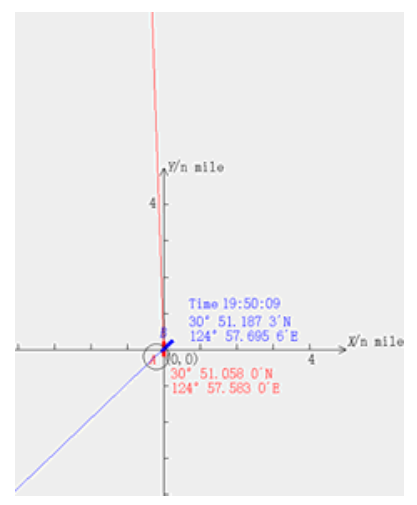

d) 0 min before collision

\subsubsection{Simulation of dynamic development rules of PPC and PCC when the bow line passes safely}

Through the simulation platform test, the two ships can safely pass through the bow line, and observe the dynamic development law of PCC and PPC.

The simulation scenarios are shown in table 3 .

The simulation test is shown in figure 7 . 


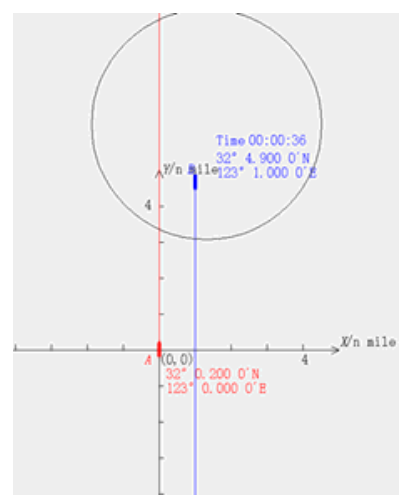

a) Long distance without crossing the line
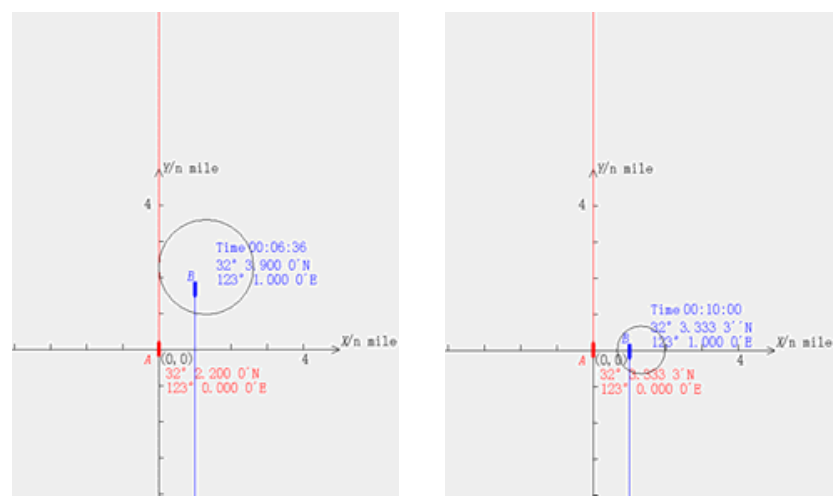

c) Clippers off the collision

d) Drive past and let clear circle

Figure 7 Simulation of dynamic development rules for the safe passage of the bow line

It can be seen from the simulation test that when the two ships are far away from PPC and the bow line is not reached: with the gradual approach of the two ships, the diameter of the collision circle shrinks and reaches the nearest approach point (CPA) of the two ships; The proportion of the clipper course line dividing collision circle changes a lot. The course line gradually separates from the collision circle and moves away from the collision circle. The PPC gradually contracts to a point and finally disappears, and gradually moves away from the collision circle.
The proportion of the collision circle divided by the slow ship's course line remains unchanged, PPC gradually moves towards the course line, and the change range is very small when arriving at the CPA point, and accelerates after arriving at the CPA point.

The whole change process is presented as a whole in one figure (the Angle between the two ships' course lines changes slightly), as shown in figure 8 .

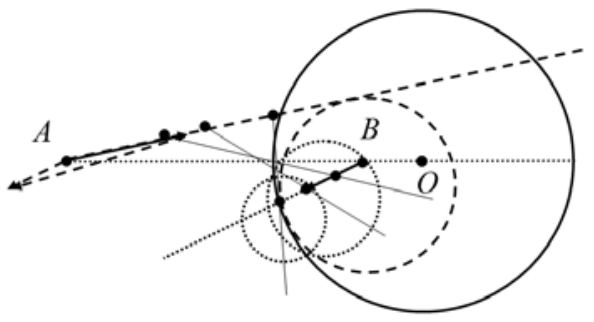

a) True exercise

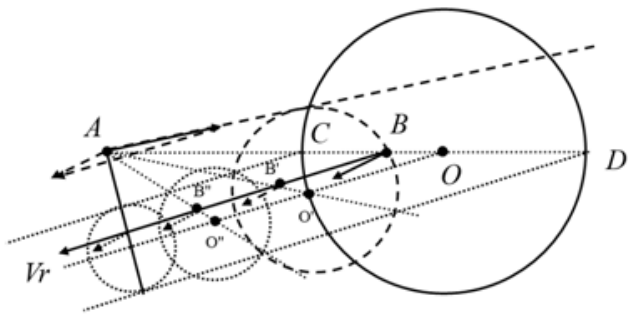

b) Relative motion

Figure 8 Shows the dynamic development rule when the bow line passes safely

\subsubsection{Simulation of dynamic development rules of PPC} and PCC when crossing the bow line safely

Through the simulation platform test, the two ships can pass through the bow line safely, and observe the dynamic development law of PCC and PPC.

The simulation scenarios are shown in table 4 .

The simulation test is shown in figure 9 .

Table 4 Scene of safe passage through the bow line

\begin{tabular}{llllll}
\hline time & ships name & ships position & speed/kn & course $/\left(^{\circ}\right)$ & PPC position \\
\hline $00: 00: 00$ & A ship & $\left(32^{\circ} 0.0000^{\prime} \mathrm{N}, 123^{\circ} 0.0000^{\prime} \mathrm{E}\right)$ & 20 & 000 & $\left(32^{\circ} 3.8277^{\prime} \mathrm{N}, 123^{\circ} 0.0000^{\prime} \mathrm{E}\right)$ \\
& $B$ ship & $\left(32^{\circ} 4.0000^{\prime} \mathrm{N}, 123^{\circ} 1.5000^{\prime} \mathrm{E}\right)$ & 10 & 270 & $\left(32^{\circ} 4.0000^{\prime} \mathrm{N}, 122^{\circ} 59.4989^{\prime} \mathrm{E}\right)$ \\
$00: 09: 00$ & A ship & $\left(32^{\circ} 3.0000^{\prime} \mathrm{N}, 123^{\circ} 0.0000^{\prime} \mathrm{E}\right)$ & 20 & 000 & $\left(32^{\circ} 3.6667^{\prime} \mathrm{N}, 123^{\circ} 0.0000^{\prime} \mathrm{E}\right)$ \\
& $B$ ship & $\left(32^{\circ} 4.0000^{\prime} \mathrm{N}, 123^{\circ} 0.0000^{\prime} \mathrm{E}\right)$ & 10 & 270 & $\left(32^{\circ} 4.0000^{\prime} \mathrm{N}, 122^{\circ} 59.4259^{\prime} \mathrm{E}\right)$ \\
$00: 10: 30$ & $A$ ship & $\left(32^{\circ} 3.5000^{\prime} \mathrm{N}, 123^{\circ} 0.0000^{\prime} \mathrm{E}\right)$ & 20 & 000 & $\left(32^{\circ} 4.0000^{\prime} \mathrm{N}, 123^{\circ} 0.0000^{\prime} \mathrm{E}\right)$ \\
& $B$ ship & $\left(32^{\circ} 4.0000^{\prime} \mathrm{N}, 122^{\circ} 59.7500^{\prime} \mathrm{E}\right)$ & 10 & 270 & $\left(32^{\circ} 4.0000^{\prime} \mathrm{N}, 122^{\circ} 59.3352^{\prime} \mathrm{E}\right)$ \\
$00: 12: 00$ & $A$ ship & $\left(32^{\circ} 4.0000^{\prime} \mathrm{N}, 123^{\circ} 0.0000^{\prime} \mathrm{E}\right)$ & 20 & 000 & \\
& $B$ ship & $\left(32^{\circ} 4.0000^{\prime} \mathrm{N}, 122^{\circ} 59.5000^{\prime} \mathrm{E}\right)$ & 10 & 270 & $\left(32^{\circ} 4.0000^{\prime} \mathrm{N}, 122^{\circ} 59.0000^{\prime} \mathrm{E}\right)$ \\
\hline
\end{tabular}




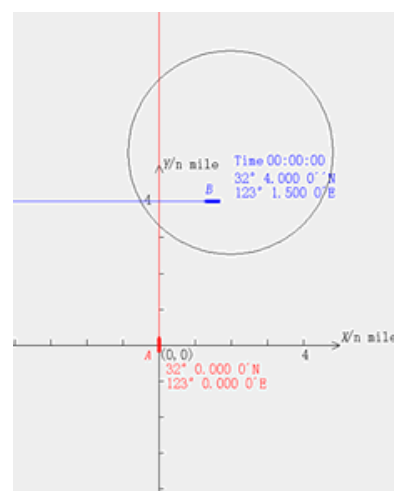

a) Before crossing the stem line

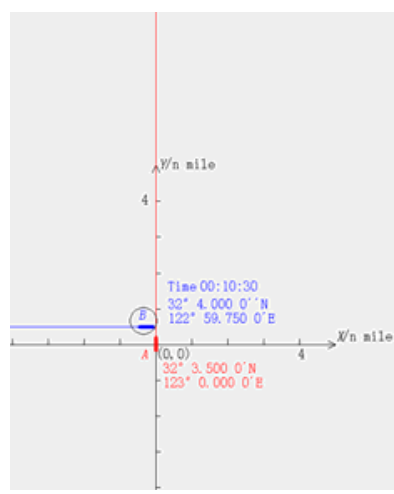

c) Clippers heading off the collision circle

Figure 9 Simulation of dynamic development rules when crossing the bow line safely

Through simulation test, it can be seen that this case also has all kinds of change rules when two ships pass through safely. Compared with the no-break bow line, the direction of the fast ship course line from the collision circle changes, which increases the change of arc degree of the cutting collision circle. The collision circle rotates with the change of the azimuth of the fast ship relative to the slow ship, and the arc of the slow ship cutting the collision circle also changes during the conversion from one side to the other.

The whole change process is presented in one picture (for the convenience of drawing, the included angle of the course line of the two ships slightly changes), as shown in figure 10 .

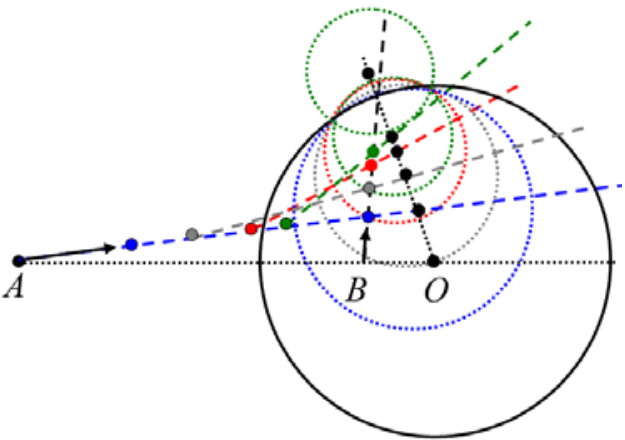

a) True exercise

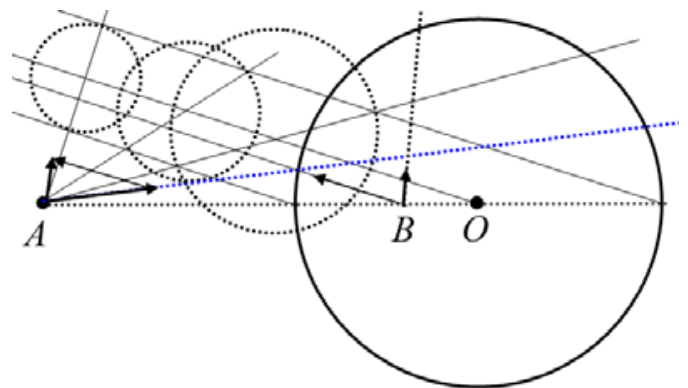

b) Relative motion

Figure 10 Dynamic development rules for safe passage through the bow line

\subsubsection{Simulation conclusion}

1 By comparing two kinds of collision simulation and two kinds of safety simulation, the dynamic development rules of PCC and PPC are analyzed. It can be seen that whether the collision points of two ships are reasonably distributed plays a decisive role in the occurrence of collision. The distribution of collision points of the two ships is easy to observe through visual processing, and can be used to comprehensively and efficiently determine whether there is a collision risk.

2 In the static analysis, the reasonable distribution of PPC between the two ships promotes the dynamic change to a favorable direction; On the contrary, the unreasonable distribution makes the dynamic change develop in an unfavorable direction.

3 In the dynamic analysis, the PPC of the two ships is located on both sides of the connection line of the two ships, and the process in which the arc degree of the collision circle of fast ship heading line cutting becomes smaller, until it is separated from and far away from the collision circle is a necessary process for the dynamic change rules of PCC and PPC in the case of no collision.

\section{SIMULATION VERIFICATION OF COLLISION AVOIDANCE MODEL BASED ON COLLISION CIRCLE}

The data of "SANCHI" (A) and "CF CRYSTAL" (B) 10 minutes before the collision were input into the simulation platform as the initial state, and the circular PPC distribution model was set as the radius parameter of 1 nautical mile to obtain the collision avoidance decision scheme and compare the collision avoidance effect. At this moment, it can be applied to the action strategy of speed maintaining steering. The decision of collision avoidance scheme and the effect of collision avoidance are shown in table 5 . 
Table 5. "SANCHI" accident using "collision-based ship collision avoidance model" decision-making collision avoidance scheme and collision avoidance index scenario

\begin{tabular}{|c|c|c|c|c|c|c|c|c|}
\hline $\begin{array}{l}\text { Collision avoidance } \\
\text { scheme }\end{array}$ & $\begin{array}{l}\text { ships } \\
\text { name }\end{array}$ & ships position & $\begin{array}{l}\text { speed } \\
/ \mathrm{kn}\end{array}$ & $\begin{array}{l}\text { decision } \\
\text { course } /\left(^{\circ}\right)\end{array}$ & $\begin{array}{l}\text { turning } \\
\text { range } /\left(^{\circ}\right)\end{array}$ & PPC position & $\begin{array}{l}\text { DCPA/ } \\
\text { n mile }\end{array}$ & $\begin{array}{l}\text { TCPA/ } \\
\text { min }\end{array}$ \\
\hline $\begin{array}{l}\text { 19:40:08 } \\
\text { The initial state }\end{array}$ & $\begin{array}{l}A \text { ship } \\
B \text { ship }\end{array}$ & $\begin{array}{l}\left(30^{\circ} 49.3150^{\prime} \mathrm{N},\right. \\
\left.124^{\circ} 57.6740^{\prime} \mathrm{E}\right) \\
\left(30^{\circ} 52.8032^{\prime} \mathrm{N},\right. \\
\left.124^{\circ} 59.5038^{\prime} \mathrm{E}\right)\end{array}$ & 13.2 & 226 & & $\begin{array}{l}\left(30^{\circ} 51.2275^{\prime} \mathrm{N},\right. \\
\left.124^{\circ} 57.6072^{\prime} \mathrm{E}\right) \\
\left(30^{\circ} 51.1663^{\prime} \mathrm{N},\right. \\
\left.124^{\circ} 57.8088^{\prime} \mathrm{E}\right)\end{array}$ & 0.19 & 10.94 \\
\hline A ship turn right & $\begin{array}{l}A \text { ship } \\
B \text { ship }\end{array}$ & $\begin{array}{l}\left(30^{\circ} 49.3150^{\prime} \mathrm{N},\right. \\
\left.124^{\circ} 57.6740^{\prime} \mathrm{E}\right) \\
\left(30^{\circ} 52.8032^{\prime} \mathrm{N},\right. \\
\left.124^{\circ} 59.5038^{\prime} \mathrm{E}\right)\end{array}$ & 10.4 & $\begin{array}{l}039 \\
226\end{array}$ & +41 & $\begin{array}{l}\left(30^{\circ} 50.6576^{\prime} \mathrm{N},\right. \\
\left.124^{\circ} 58.7612^{\prime} \mathrm{E}\right) \\
\left(30^{\circ} 51.1663^{\prime} \mathrm{N},\right. \\
\left.124^{\circ} 57.8088^{\prime} \mathrm{E}\right)\end{array}$ & 1.03 & 9.69 \\
\hline A ship turn left & $\begin{array}{l}A \text { ship } \\
B \text { ship }\end{array}$ & $\begin{array}{l}\left(30^{\circ} 49.3150^{\prime} \mathrm{N},\right. \\
\left.124^{\circ} 57.6740^{\prime} \mathrm{E}\right) \\
\left(30^{\circ} 52.8032^{\prime} \mathrm{N}\right. \\
\left.124^{\circ} 59.5038^{\prime} \mathrm{E}\right)\end{array}$ & 10.4 & 331 & -27 & $\begin{array}{l}\left(30^{\circ} 51.5897^{\prime} \mathrm{N},\right. \\
\left.124^{\circ} 56.4131^{\prime} \mathrm{E}\right) \\
\left(30^{\circ} 51.1663^{\prime} \mathrm{N}\right. \\
\left.124^{\circ} 57.8088^{\prime} \mathrm{E}\right)\end{array}$ & 0.96 & 12.20 \\
\hline B ship turn right & $\begin{array}{l}A \text { ship } \\
B \text { ship }\end{array}$ & $\begin{array}{l}\left(30^{\circ} 49.3150^{\prime} \mathrm{N},\right. \\
\left.124^{\circ} 57.6740^{\prime} \mathrm{E}\right) \\
\left(30^{\circ} 52.8032^{\prime} \mathrm{N}\right. \\
\left.124^{\circ} 59.5038^{\prime} \mathrm{E}\right)\end{array}$ & 10.4 & 358 & +29 & $\begin{array}{l}\left(30^{\circ} 51.2275^{\prime} \mathrm{N},\right. \\
\left.124^{\circ} 57.6072^{\prime} \mathrm{E}\right) \\
\left(30^{\circ} 51.7139^{\prime} \mathrm{N},\right. \\
\left.124^{\circ} 55.4385^{\prime} \mathrm{E}\right)\end{array}$ & 0.96 & 12. 36 \\
\hline B ship turn left & $\begin{array}{l}A \text { ship } \\
B \text { ship }\end{array}$ & $\begin{array}{l}\left(30^{\circ} 49.3150^{\prime} \mathrm{N},\right. \\
\left.124^{\circ} 57.6740^{\prime} \mathrm{E}\right) \\
\left(30^{\circ} 52.8032^{\prime} \mathrm{N},\right. \\
\left.124^{\circ} 59.5038^{\prime} \mathrm{E}\right)\end{array}$ & 10.4 & 358 & -24 & $\begin{array}{l}\left(30^{\circ} 51.2275^{\prime} \mathrm{N},\right. \\
\left.124^{\circ} 57.6072^{\prime} \mathrm{E}\right) \\
\left(30^{\circ} 50.7865^{\prime} \mathrm{N},\right. \\
\left.124^{\circ} 58.5218^{\prime} \mathrm{E}\right)\end{array}$ & 1.11 & 9.83 \\
\hline
\end{tabular}

In the "SANCHI" accident scene, the "collision circle based ship collision avoidance decision model" is used to determine the collision avoidance process and the collision avoidance effect, as shown in figure 11.

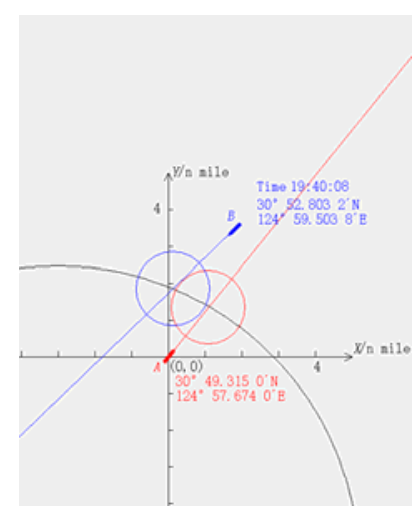

a) A turn right

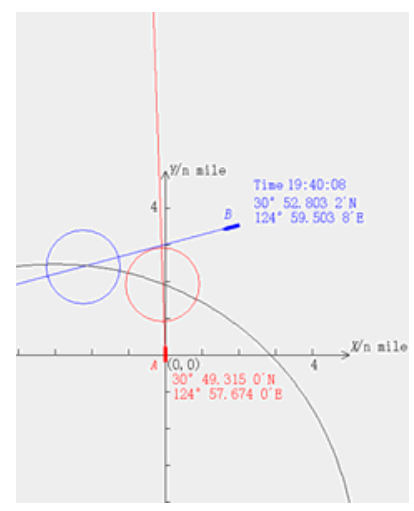

c) B turn right

Figure 11. Simulation of collision avoidance decision of "SANCHI" scene

In combination with the international regulations for preventing collisions [23], and both ship should choose a right scheme, using collision circle collision avoidance decision-making model to calculate fast and efficient to amplitude and DCPA and requirement of the ship's index, through visualization can clearly see that the distribution of PPC in an allround way, the collision avoidance decision-making scheme and the results meet the requirements of the "international regulations for preventing collisions at sea", as shown in table 6 .

Table 6. Avoidance decision scheme in "SANCHI" accident scenario

\begin{tabular}{llllll}
\hline plan & $\begin{array}{l}\text { ships } \\
\text { name }\end{array}$ & $\begin{array}{l}\text { decision } \\
\text { course } /\left(^{\circ}\right)\end{array}$ & $\begin{array}{l}\text { turning } \\
\text { range } /\left(^{\circ}\right)\end{array}$ & $\begin{array}{l}\text { DCPA/ } \\
\text { n mile }\end{array}$ & $\begin{array}{l}\text { TCPA/ } \\
\text { min }\end{array}$ \\
\hline A ship & A ship & 039 & +41 & 1.03 & 9.69 \\
turn right & $B$ ship & 226 & & & \\
B ship & $A$ ship & 358 & & 0.96 & 12.36 \\
turn right & $B$ ship & 255 & +29 & & \\
\hline
\end{tabular}

\section{CONCLUSION}

The collision circle model has the advantages of well adapting to the change of speed, course and position, and the "collision circle ship collision avoidance decision model" is applied to evaluate and visualize the decision-making, which to some extent solves the problem of poor effect of comprehensive evaluation and efficient decision-making for ships. The collision circle model was used to simulate the accident scene of "SANCHI", and the results showed that the proposed collision avoidance scheme met the requirements of "international rules for collision avoidance at sea" and safety requirements, which proved the feasibility of the model and provided an objective and efficient method for collision avoidance. The PPC distribution model corresponds to different geometric relationships in different situations, and the parameter setting of the geometric model is highly subjective based on experience. Therefore, how to flexibly select the appropriate model and improve the 
setting of geometric parameters will require further research and experiments.

\section{REFERENCES}

[1] Huang Ying, Li Lina, Chen guoquan. Design and application of decision support module for collision avoidance of urgent danger [J]. Journal of jimei university: natural science edition, 2011, 16(6).

[2] $\mathrm{Wu}$ Zhaolin. Selection of collision avoidance actions based on PAD information and improvement of PAD graphics [J]. Journal of dalian maritime university, 1986(4):16-26.

[3] Fang Xianglin, Fu Wanxuan. Danger zone model for velocity ratio circle prediction and its application in ARPA system [J]. China maritime, 1984(2):5-17.

[4] Wang Renqiang, Zhao Yuelin, Xie Baofeng. Mathematical model of collision avoidance in ship dynamic steering [J]. Journal of dalian maritime university, 2014, 40(1):17-20.

[5] He Yixiong, Huang Liwen, Mou Junmin, et al. Automatic collision avoidance action plan for give-way vessels in cross-encounter situation [J]. Journal of Harbin engineering university, 2015(08):1024-1029.

[6] Xiong Yong, He Yixiong, Huang Liwen. Multi-ship automatic collision avoidance control method based on speed obstacle [J]. China maritime, 2015, 38(3).

[7] Chen Yaojie, Li Shuang, Fan Huan, et al. Research on multi-ship automatic collision avoidance based on velocity vector coordinate system [J]. Computer simulation,2015,32(6):420-424.

[8] Liao Bingjun. Introduction to safety situation diagram avoidance method [J]. Navigation technology,2018.

[9] Hu Shenping. Classification and quantification of collision avoidance stage in ship encounter process [J]. China maritime industry, 2001(2):83-87.

[10] Hu Qiaoer, Hu Qinyou. Design and analysis of ship collision avoidance simulation system based on negotiation [J]. China maritime, 2009, 32(1):54-59.

[11] You Y, Rhee K. Development of the collision ratio to infer the time at which to begin a collision avoidance of a ship[J]. Applied Ocean Research, 2016, 60:164-175.
[12] Ma Wenyao, Wu Zhaolin, Yang Jiaxuan, et al. Decision support for collision avoidance path planning of artificial fish swarm algorithm [J]. China maritime, 2014, 37(3):63-67.

[13] Ni Shengke, Liu Zhengjiang, Cai Yao, et al. Collision avoidance decision support for ships based on genetic algorithm [J]. Journal of Shanghai maritime university, 2017(1).

[14] Yu Jiagen, Liu Zhengjiang, Bu Renxiang, et al. Collision avoidance decision of ship steering based on simulation physics optimization algorithm [J]. China maritime, 2016, 39(1):36-38.

[15] Yang Baicheng, Zhao Zhilei. Multi-ship collision avoidance decision based on improved simulated annealing algorithm [J]. Journal of dalian maritime university, 2018, 44(2).

[16] Wang Deyan, liu Yian. Application of particle swarm optimization in multi-ship collision avoidance decision [J]. Computer engineering and design, 2009, 30(14):33803382.

[17] Shen Haiqing, Guo Chen, Li Tieshan, et al. Intelligent collision avoidance navigation method for unmanned ships considering rules of navigation experience [J]. Journal of Harbin engineering university, 2018, 260(06):48-55.

[18] Huang Y, P. H. A. J. M. van Gelder, Wen Y. Velocity obstacle algorithms for collision prevention at sea[J]. Ocean Engineering, 2018, 151:308-321.

[19] Liu Renwei, Xue Yanzhuo, Liu Yang, et al. Automatic collision avoidance model and its application in restricted waters [J]. Journal of Harbin Institute of Technology, 2018(3).

[20] Li Lina, Xiong Zhennan, Gao Yansong, et al. Generation and optimization method of single ship collision avoidance intelligent decision [J]. Information and control, 2002, 32(2):189-192.

[21] Zhuo Yongqiang, and T. Tang . "An intelligent decision support system to ship anti-collision in multi-ship encounter. "World Congress on Intelligent Control \& Automation IEEE, 2008.

[22] LAZAROWSKA A. Ant Colony Optimization based Navigational Decision Support System [J]. Procedia Computer Science, 2014, 35:1013-1022.

[23] Zhao jin-song, wang feng-chen, et al. Collision and collision avoidance rules. Dalian maritime university press, 1997. 